\title{
Review: \\ Developments on Synthesis and Applications of Sulfobetaine Derivatives: A Brief Review
}

\author{
Eva Oktavia Ningrum ${ }^{1 *}$, Eva Lestiana Pratiwi ${ }^{1}$, Isyarah Labbaika Shaffitri ${ }^{1}$, Suprapto Suprapto ${ }^{1}$, \\ Mentari Rachmatika Mukti ${ }^{2}$, Ely Agustiani ${ }^{1}$, Niniek Fajar Puspita ${ }^{1}$, and Achmad Dwitama Karisma ${ }^{1}$ \\ ${ }^{1}$ Department of Industrial Chemical Engineering, Faculty of Vocational Studies, Institut Teknologi Sepuluh Nopember, \\ Kampus ITS Sukolilo, Surabaya, 60111, Indonesia
}

${ }^{2}$ Department of Fossil Fuels, Faculty of Geology, Geophysics and Environmental Protection, AGH University of Science and Technology, al. Mickiewicza 30, 30-059, Cracow, Poland

\section{${ }^{*}$ Corresponding author:}

email:eva-oktavia@chem-eng.its.ac.id

Received: November 6, 2020

Accepted: March 3, 2021

DOI: $10.22146 /$ ijc. 61128

\begin{abstract}
Zwitterionic polymers are material families characterized by high dipole moment and highly charged groups. Zwitterionic materials simultaneously possess an equimolar number of cationic and anionic moieties, maintaining overall electroneutrality and high hydrophilicity. Zwitterionic is categorized into three groups: phosphobetaine, carboxybetaine, and sulfobetaine that could form dense and stable hydration shells through the strong ion-dipole interaction among water molecules and zwitterions. As a result of their remarkable hydration capability, low interfacial energy, and marvelous antifouling capacities, these materials have been applied as adsorbing agents, biomedical applications, electronics, hydrogels, and antifouling for membrane separation and marine coatings. This review is focused on polysulfobetaine, which contains sulfonate as a negatively charged group, and quaternary ammonium as a positively charged group. Polysulfobetaine is the most promising one to be applied in the industry since it is commercially available and its monomers are easily prepared. The comparisons of several polysulfobetaine derivatives as antimicrobial, antifouling, surfactant and detergents, biomedical and electronic application, surface modification, and smart hydrogel are presented in this review.
\end{abstract}

Keywords: zwitterionic; sulfobetaine; antifouling; biomedical application

\section{- INTRODUCTION}

Significant amounts of novel materials have been widely explored and produced in industrial, electronic, biotechnological, and biomedical applications over the last few decades. Zwitterionic polymers are currently one of these materials that, for their super hydrophilicity, biocompatibility, and antifouling properties, have received a lot of attention in biomaterials [1]. Zwitterionic compounds, which have strongly charged groups and high dipole moment, have an equimolar amount of cationic and anionic moieties, preserving total electroneutrality and high hydrophilicity [2-3]. Unlike polyethylene glycol (PEG) water which employed hydrogen-bond interaction to bind molecules, zwitterions build stronger hydration shells through iondipole interaction with denser and tighter adsorbed water [4]. This fact eventually drives extremely poor nonspecific protein adsorption, bacterial adhesion, and biofilm formation, causing zwitterions to be preferred replacements for POLYETHYLENE GLYCOL (PEG) [5]. Zwitterionic materials have other benefits in addition to their excellent antifouling property, in which this material can also improve biocompatibility, minimize the immune response, extend circulation time, and facilitate cellular absorption of conventional chemical drugs and therapeutic genes. 
Zwitterionic polymers are material families whose cation and anion groups have an equal amount on the molecular chains. Zwitterionic polymer betaine is generally thermosensitive in an aqueous solution. It is insoluble in the water below the Upper Critical Solution Temperature (UCST) but dissolves above UCST temperature [6-8]. When the zwitterionic polymers are at temperatures below Upper Critical Solution Temperature, intrachain and interchain interactions occur, causing them to experience collapse coil conditions [9]. On the other hand, when the polymers are at temperatures above UCST, the thermal energy overcomes the obstacles due to intrachain and interchain interactions [10]. The zwitterionic UCST polymer increases as the polymer concentration increases since the intrachain and interchain interactions increase, so thermal energy must be improved to overcome these interactions [11]. These interactions between charged groups in zwitterionic betaine and aqueous solutions also determine zwitterionic betaine properties [12-13].

According to the anions, zwitterionic groups are categorized into sulfobetaine (SB), carboxybetaine (CB), and phosphobetaine (PB). Meanwhile, cations are generally quaternized ammonium [14]. These polymers become the main aspect of practical applications and fundamental scientific studies for several reasons, including their well-defined phase transitions in aqueous solutions, zwitterionic characteristics, and potential applications as complexation materials, ion exchange, catalysts, compatible drugs, and blood [15], macrocycles [16-18], stabilization of protein [19-20], as well as electronic application [21-23].

Among these polymers, zwitterionic parts containing SB structures of ammonium cations and sulphonate anions isolated with alkyl groups have been extensively developed due to their interesting characteristics related to their bio and easy synthesis [24]. The most promising polymers to be applied in the industry is polysulfobetaine (PSB) since it is commercially available, and its monomers are easily prepared. Furthermore, CB has several superiorities among the other zwitterionic materials, including their super antifouling properties [25], good biocompatibility [26], and functionality, making it considerable interest. Like $\mathrm{CB}, \mathrm{PB}$ has excellent blood compatibilities and bio compatibilities, but its application is limited due to its high production cost [14]. One of the subclasses of zwitterionic sulfobetaine polymer is PSB. PSB contains sulfonate as the negatively charged group and quaternary ammonium as the positively charged group. Sulfobetaine is synthesized through alkylsulfonation reaction of monomers or tertiary amine polymers with sultone, for example, 1,3-propanesultone or 1,4butanesultone. At the beginning of its discovery, betaine polymers are derived from sulfo-compounds. Its chemical structure can also be derived from the following compounds: esters or amide quaternary from methacrylic acid, poly(pyrrolidinium) quaternary compounds, ionenes, and poly(vinyl pyridinium) or poly(vinyl imidazolium) compounds [12].

In this short paper, a systematic review is made on PSB derivatives' research and development related to their property characterization, synthesis development, and importance antimicrobial, antifouling, surfactant, detergents, biomedical and electronic devices surface modification, and innovative hydrogel applications. Other issues regarding the limitation and future trends are also elucidated in this review.

\section{- DISCUSSION}

\section{Polysulfobetaine as an Adsorbing Agent (Antimicrobial)}

Peptidomimetic polymers are materials used as adsorbing agents (antimicrobial) and antifouling. However, these polymers have no resistance to serum adsorption and only have a $75 \%$ surface adsorption rate in plasma [27]. Sulfobetaine polymer derivatives can be used as antimicrobial because they have catechols, a versatile, efficient, and comfortable technique that can also become a stable barrier from zwitterionic polymers to the surface. One of the derivatives is polysulfobetaine (PSB). PSB can be applied as an antimicrobial in blood plasma. Research conducted by Li et al. [28] found an example of PSB derivatives' application by grafting PSBcatechol polymers to the surface to fight bacteria or microbes in the blood. As explained before, catechol 


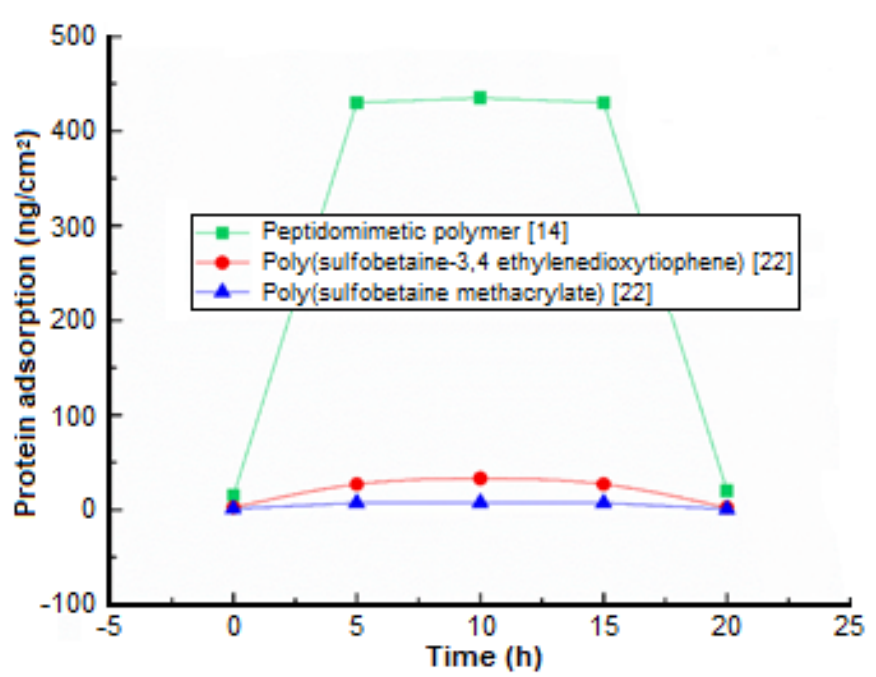

Fig 1. Protein adsorption rate of different sulfobetaine derivatives

derivatives can be a versatile, efficient, and comfortable technique that is a stable barrier from zwitterionic polymers to the surface. Previous research [27] obtained that adhesive protein derived from shells inspires DOPA or catechol derivatives and has been successfully employed in the functional modification of the material surface.

Other previous research [28-33] found that PSB can be applied as an adsorbing agent. This research is an initial study, which presents that the surface of zwitterionic poly(sulfobetaine methacrylate) and poly(carboxybetaine methacrylate) (pCBMA) are very resistant to the adsorption of nonspecific proteins with $<0.3 \mathrm{ng} / \mathrm{cm}^{2}$ fibrinogen adsorption level. This study was conducted based on zwitterionic monomers' surface grafting through atomic transfer radical polymerization (ATRP). In a study conducted by Li et al. [28], a single soft negatively charged protein from fibrinogen (Fg) and a hard positively charged protein from lysozyme (Lyz) along with $10 \%$ blood serum were employed as a model to investigate the non-decaying properties of the surface coated with PSBMA-catechol. The test results showed a representative SPR sensorgram of the $\mathrm{NH}_{2}-\mathrm{Au}$ PSBMA300-catechol surface exposed to human plasma and undiluted serum showing the non-decaying nature of this surface layer. This layer had average protein adsorption of $7.3 \mathrm{ng} / \mathrm{cm}^{2}$ and $7.5 \mathrm{ng} / \mathrm{cm}^{2}$ of $100 \%$ plasma and serum, respectively, showing the non-fouling properties of PSBMA300, which are excellent surfaces coated with catechols.
Based on Fig. 1, protein adsorption on peptidomimetic polymer is higher than on poly(sulfobetaine-3,4 elthylenedioxytiophene) and poly(sulfobetaine methacrylate). Therefore, it can be concluded that polysulfobetaine can be employed as adsorbing agents.

In a previous study conducted by Jiang and Cao [34], they successfully grafted PSB-catechol polymers to the surface to fight bacteria in the blood. Adhesive protein derived from shells inspires DOPA or catechol derivatives and has been successfully employed in the functional modification of the material surface (Table 1). The test resulted that the grafted PSB surface via ATRP under the optimal film can withstand the adsorption of protein $10 \%$ serum from $100 \%$ blood serum; thus, the results achieved by PSB-catechol through the graft to the method were considered exceptional. For a practical, comfortable, and stable buffer from zwitterionic polymers to the surface, catechol derivatives can be used as a flexible method. PSB-catechol polymers with controlled molecular weight were synthesized through ATRP SB monomers initiated by bromide attached to catechols with oxygen protected by t-butyldimethylsilyl (TBDMS) [28]. The test results showed that the serum adsorption power was $27 \%$, while the plasma adsorption power was around $75 \%$. This fact indicates that plasma adsorption is more significant than serum adsorption [27] (Table 1). Antifouling properties of poly(SB-3,4ethylene dioxythiophene) (PSBEDOT) gold-coated used $100 \%$ human blood plasma and 30\% human blood serum, which are complex protein solutions. As an antimicrobe/antifouling, PSBEDOT can also be shifted electrically, and the best electrical efficiency was used as backbone conduction. Furthermore, the monomer was polymerized on the electrode. The explanation of these sentences can be seen in Table 1, which is the comparison of the use of sulfobetaine derivatives as adsorption agents obtained from previous studies.

\section{Sulfobetaine as Antifouling}

PSB also have electro-switchable antifouling characteristics and excellent electrical efficiency; thus, they can also minimize the fouling and raise the biocompatibility of bioelectronics performance. For 
Table 1. The comparison of sulfobetaine derivatives properties as adoption agents (antimicrobials)

\begin{tabular}{|c|c|c|c|c|}
\hline Criteria & $\begin{array}{l}\text { Peptidomimetic } \\
\text { polymers }\end{array}$ & $\begin{array}{l}\text { poly(sulfobetaine-3,4- } \\
\text { ethylene dioxythiophene) }\end{array}$ & $\begin{array}{l}\text { Poly(sulfobetaine } \\
\text { methacrylate) }\end{array}$ & Ref. \\
\hline Characteristic & $\begin{array}{l}\text { Robust, waterproof resistant } \\
\text { to environmental impurities }\end{array}$ & $\begin{array}{l}\text { Resistant to adsorption and } \\
\text { impurity }\end{array}$ & $\begin{array}{l}\text { Adsorption, bacterial } \\
\text { adhesion, and biofilm } \\
\text { formation resistance }\end{array}$ & {$[27-28,35]$} \\
\hline $\begin{array}{l}\text { Plasma adsorption } \\
\text { resistance }\left(\mathrm{ng} / \mathrm{cm}^{2}\right)\end{array}$ & 435 & 28 & 7.3 & {$[27-28,35]$} \\
\hline $\begin{array}{l}\text { Serum adsorption } \\
\text { resistance }\left(\mathrm{ng} / \mathrm{cm}^{2}\right)\end{array}$ & - & 33 & 7.5 & {$[28,35]$} \\
\hline Surface coating & DOPA/Catechol & Gold pieces & Catechol & {$[27-28,35]$} \\
\hline $\begin{array}{l}\text { Serum surface } \\
\text { adsorption (\%) }\end{array}$ & 27 & 30 & 10 & {$[27-28,35]$} \\
\hline $\begin{array}{l}\text { Plasma surface } \\
\text { adsorption (\%) }\end{array}$ & 75 & 100 & 100 & {$[27-28,35]$} \\
\hline Polymers design & $\begin{array}{l}\text { It consists of a short } \\
\text { functional peptide domain }\end{array}$ & $\begin{array}{l}\text { Electro-switchable } \\
\text { antimicrobial/antifouling } \\
\text { characteristics and excellent } \\
\text { electrical efficiency }\end{array}$ & $\begin{array}{l}\text { Fibrinogen adsorption is } \\
\text { limited to a degree equal } \\
\text { to PEG-like film } \\
\text { adsorption }\end{array}$ & {$[30-32,35-36]$} \\
\hline Synthesis & $\begin{array}{l}\text { Backbone similar to protein } \\
\text { with derivatization of the side } \\
\text { chain on the amide nitrogen } \\
\text { instead of the R-carbon }\end{array}$ & $\begin{array}{l}\text { PEDOT is used as the } \\
\text { conducting backbone. On } \\
\text { electrodes, monomers are } \\
\text { polymerized on electrodes }\end{array}$ & $\begin{array}{l}\text { Grafted through atom } \\
\text { transfer radical } \\
\text { polymerization (ATRP) } \\
\text { on a gold surface }\end{array}$ & $\begin{array}{l}{[2-3,30-31} \\
36-40]\end{array}$ \\
\hline Function & Used in bioseparations & Used in bioelectronics & $\begin{array}{l}\text { Used in adsorption } \\
\text { protein }\end{array}$ & {$[35,41-42]$} \\
\hline
\end{tabular}

example, the poly(SB-3,4-ethylene dioxythiophene) (PSBEDOT) surface has excellent electro-switchable antimicrobial/antifouling characteristics and electrical efficiency. The electrochemical method is further can be used for the polymerization of zwitterionic PSBEDOT in an aqueous solution. The impedance of the PSBEDOT interface is less than $10 \%$ than pure gold at low frequencies. The previous research found that PSBEDOT also owns antifouling characteristics to all mammalian cells, blood, and bacteria performs excellent electrochemical properties, low interface impedance and stability, and transferable antifouling/antimicrobial characteristics. The surface of PSBEDOT can also shift between cationic and zwitterionic antifouling antimicrobials. It can kill many cells in a small amount of time and volts, and while it is under static conditions, it can release several dead cells in an hour. This new material can significantly boost efficiency and service life, reduce foreign body reactions and bio-electronic system contamination, and enhance biocompatibility [35].

Protein adsorption on PSB is higher than polyethylene glycol. Furthermore, bacteria adhesion on poly(sulfobetain) is also higher than poly(ethilene glycol). So that, it can be summed up that adsorption consistency and PSB adhesion are better than poly(ethylene glycol) and poly(sulfobetain) can be used as antifouling (Fig. 2).

In principle, fouling is the product of protein adsorption, deposition, denaturation, and aggregation at the membrane interface during ultrafiltration. The membrane surface was modified using hydrophilic molecules, such as poly(ethylene glycol) (PEG) and zwitterionic to prevent fouling (Table 2). Random copolymer ((2-dimethylamino acrylonitrile ethyl methacrylate) was synthesized through water phase suspension polymerization of 2-dimethylamino ethyl 
methacrylate using acrylonitrile. A random copolymer poly((2-dimethylamino athyl methacrylate)-acrylonitrile) (PAN-DMAEMA) was then reacted with 1,3-propane sulfone to convert the DMAEMA group to zwitterionic $\mathrm{N}, \mathrm{N}$-dimethyl- $\mathrm{N}$-methacryloxyethyl- $\mathrm{N}$-(3-functional group sulfopropyl) (DMMSA). PAN-based zwitterionic copolymers were then mixed with poly(acrylonitrile) to make ultrafiltration membranes. Ultrafiltration experiments found that particularly irreversible membrane impurities were significantly reduced due to the merger of zwitterionic DMMSA classes [43]. A study conducted by Wei et al. [44] on PEG as an antifouling explained that they modified stainless steel with a highdensity PEG layer aimed at preventing the adsorption of protein (b-lactoglobulin) and bacterial adhesion of Pseudomonas sp. and L. monocytogenes. Pseudomonas sp. produces a biosurfactant called rhamnolipid, which is used to dissolve material hydrocarbon by improving its biodegradation rate. Biosurfactant produced can remove PEG complex so that it cannot prevent protein adsorption and bacteria adhesion. The optimized PEG surface was proven to avoid adsorption protein but did not reduce the bacterial adhesion, as shown in Fig. 2. Table 2 shows the data comparison on the use of PSB and PEG derivatives as antifouling.

The other applications of PSB are for membrane separation and marine coating [14]. Due to its high process performance, low energy use, fast scale-up, and negligible environmental effects, membrane separation technology have been generally used for wastewater management, urban drinking water treatment, environmental engineering, and food production [45]. According to a report, compared to a series of charged and neutral membranes with similarly identical pore sizes, zwitterionic membranes have the best resistance characteristics of protein adsorption [46]. Therefore, zwitterionization is an efficient process for changing the membrane separation surface. Among the zwitterions, PSB is most generally employed due to their commercial availability and low cost. Biofouling is the most problematic fouling type since even small amounts of microorganisms that escape the pretreatment processes can colonize the system; thus, adding issues at the membrane surface. Surface modification is an effective way to increase the $\mathrm{RO}$ membranes' fouling resistance [47]. One of the main benefits of sulfobetaine-3,4ethylenedioxythiophene (SBEDOT) monomer is its very dissolving abilities in the water and can be directly

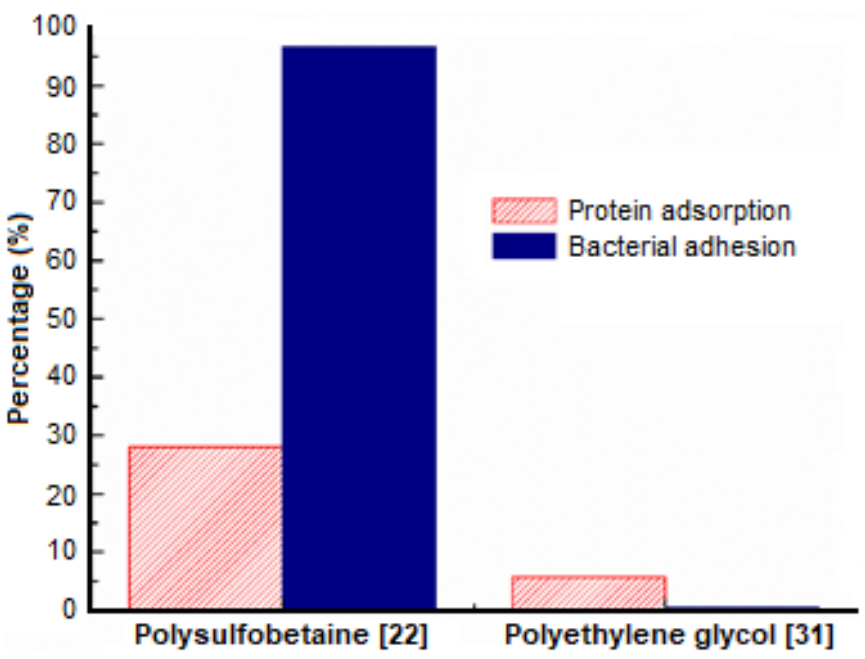

Fig 2. Level of bacterial adhesion and protein adsorption

Table 2. The comparison of PEG and PSB properties as antifouling

\begin{tabular}{|c|c|c|c|}
\hline Criteria & Poly(ethylene glycol) & $\begin{array}{l}\text { Poly(sulfobetaine-3,4- } \\
\text { ethylenedioxythiophene) }\end{array}$ & Ref. \\
\hline Raw material & Available, cheap price & Available, cheap price & {$[35,44]$} \\
\hline Solubility & $\begin{array}{l}\text { Soluble in water, using } \\
\text { biosurfactants }\end{array}$ & $\begin{array}{l}\text { Soluble in water and soon polymerized } \\
\text { in an aqueous solution without using } \\
\text { surfactants or organic solvents }\end{array}$ & {$[35,43-44]$} \\
\hline Characteristics & $\begin{array}{l}\text { Resistant to adsorption and } \\
\text { impurity }\end{array}$ & $\begin{array}{l}\text { Resistant to adsorption, adhesion, and } \\
\text { impurity }\end{array}$ & {$[27,35,43]$} \\
\hline Adsorption power (\%) & 5.7 & 28 & {$[35,44]$} \\
\hline Adhesion power (\%) & $<0.5$ & 96.7 & {$[35,44]$} \\
\hline Impedance (\%) & - & $<10$ & {$[35]$} \\
\hline
\end{tabular}


polymerized in the solution water without using organic solvent or surfactant. In this case, the amount of adsorption was $28 \%$, while the amount of adhesion was 96.7\% (Table 2). Owing to the very rugged and charged surface of the active polyamide substrate, thin-film composite (TFC) reverse osmosis membranes are especially vulnerable to biofouling. Therefore, the coating materials should: (i) be charge-neutral; (ii) have a low surface roughness (microscale); (iii) be hydrophilic; and (iv) have stable surface hydration [47].

The resistance of TFC membranes with hydrophilic PEG towards nonspecific protein adsorption has been improved through chemical modification. However, when oxygen or transition metal ions exist, PEG molecules are easily auto-oxidized [48]. The development of hydrophilic polyzwitterionic coatings has also been done according to the natural anti-biofouling characteristics of cell membranes provided by phosphatidylcholine lipid head groups. Zwitterionic betaine polymers, including PSB, poly(carboxybetaine) $\mathrm{PCB}$, and poly(phosphor-betaine) PPB attached to the different surfaces by applying various techniques, are chemically stable. Zwitterionic coatings are considered the most effective anti-biofouling materials because zwitterionic surfaces can decrease cell and bacterial adhesion [49].

Ginic-Markovic et al. have researched PSB grafting onto commercially available reverse osmosis membrane surfaces for desalination technology. The study examined the biofouling resistance of modified membranes through surface amine groups' reaction with a 2-bromoisobutyryl bromide atom transfer radical polymerization (ATRP) initiator, followed by polymerization initiated from the surface using ATRP regenerated electron transfer activators (ARGET). Such 'grafting from' route produces narrow molecular weight distribution polymers without strict experimental conditions required for other ATRP processes [47] and allows higher densities of polymers than the 'grafting to' method [50]. Using surface-initiated ARGET-ATRP, PSB was successfully grafted off the surface of commercially available TFC membranes. The reaction conditions were optimized to build stable covalently bound polyzwitterionic brushes creating hydrophilic and smooth surfaces. In aquaria experiment and hydrodynamic measurements for PSB coated RO desalination membranes, at least $80 \%$ of the microbial biofouling decreased compared to controls, retaining a competitive permeation flux [51].

\section{Sulfobetaine Derivatives in the Form of Surfactants and Detergents}

Although surfactants act significantly in biochemical membranes, the production of surfactant reagents for synthesis is minimal, making surfactants challenging to find. Brij and Triton series belong to nonionic surfactants, which are heterogeneous mixtures of closely related compounds and have physical characteristics related to the average composition. Bile anion salts are deposited at modest $\mathrm{pH}$ values, and the complex forms do not dissolve with divalent cations such as $\mathrm{Ca}^{2+}$ and $\mathrm{Mg}^{2+}$. Other surfactants show their cap at $4{ }^{\circ} \mathrm{C}$, such as deoxycholate and sodium dodecyl sulfate [52]. According to [52], detergents are very well-known for their application in biochemistry. The characteristic features of detergents that can be applied in biochemistry are:

(i) Detergents should be homogeneous with organic compounds that have known properties, such as molecular weight.

(ii) Detergents must not be denatured. In this case, detergents must not interact with the protein's secondary or tertiary structure.

(iii) Detergents must be efficiently neutral and have a zero net charge.

(iv) The detergent property should only display a minimal response to $\mathrm{pH}$, ionic strength, and temperature.

(v) Detergents must be able to dissolve freely from 0 to $100^{\circ} \mathrm{C}$.

PSB is produced from the reaction between fatty acids reacts with sodium 3-chloro-2-hydroxy-1-propane sulfonate by adding sodium bisulfite. To decrease the hydrolysis level of the 3-chloro compound and thus increase the desired compound yield, the reaction conditions between aminoamide and sodium 3-chloro2-hydroxy-l-propane sulfonate were explored. Investigating the quaternization of aminoamide with 
allyl chloride showed that this reaction takes place easily at pressures above the atmosphere. Complexes formed by sodium bisulfite addition to allyl quaternary ammonium occur quickly in some free-radical initiators' presence. The formulation of ternary soap detergents, glass silicate builders, and PSB are the same as those obtained with ternary formulations consisting of analog PSB retrieved from the reaction between propane sultone and aminoamides [53].

As shown in Fig. 3, soap fats of $\mathrm{N}$-alkylglutaramides and apamides are higher than amide fats. Furthermore, amphoteric surfactant amide fats are higher than $\mathrm{N}$ alkylglutaramides and apamides, while sodium silicate among $\mathrm{N}$-alkylglutaramides, apamides, and amide fats same. Therefore, the derivatives of SB can be in the form of $\mathrm{N}$-alkylglutaramides and apamides, and amide fats.

Hydrochloric acid from methyl hydrogen glutaric and methyl hydrogen adipate can react with various primary fat amines. The amido ester is converted to amino diamide by the catalyzed reaction of sodium with $\mathrm{N}, \mathrm{N}$-dimethylamino-alkylamines, while the desired PSB is obtained from the reaction of $N$-alkyl- $N^{\prime}-(1,1-$ dimethylaminoalkyl) glutaramides and adipamides with 1,3-propanesultone. Its composition has a dispersion of lime soap with good ability, water-solubility, calcium ion stability, and detergency properties as an analog succinamide derivative. The distance between the quaternary nitrogen atom and the nearest amido group between the two amido groups does not affect the surface's active characteristics [54].
Detergency for amide fat detergent/surfactant formulations composed of $65 \%$ fat soap, $20 \%$ amphoteric surfactants, and $15 \%$ sodium silicate. Nalkylglutaramides and apamides consist of $75 \%$ fat soap, $10 \%$ amphoteric surfactants, and $15 \%$ sodium silicate. The comparison of sulfobetaine derivatives use for detergents/surfactants is shown in Table 3.

\section{Sulfobetaine Applications \\ Derivatives for Biomedical}

Methyl $\left(\mathrm{CH}_{3}\right)$ and oligo ethylene glycol (OEG) are common materials used for medical applications [42]. OEG is the most widely used material for biomedical applications. However, OEG is vulnerable to oxidation

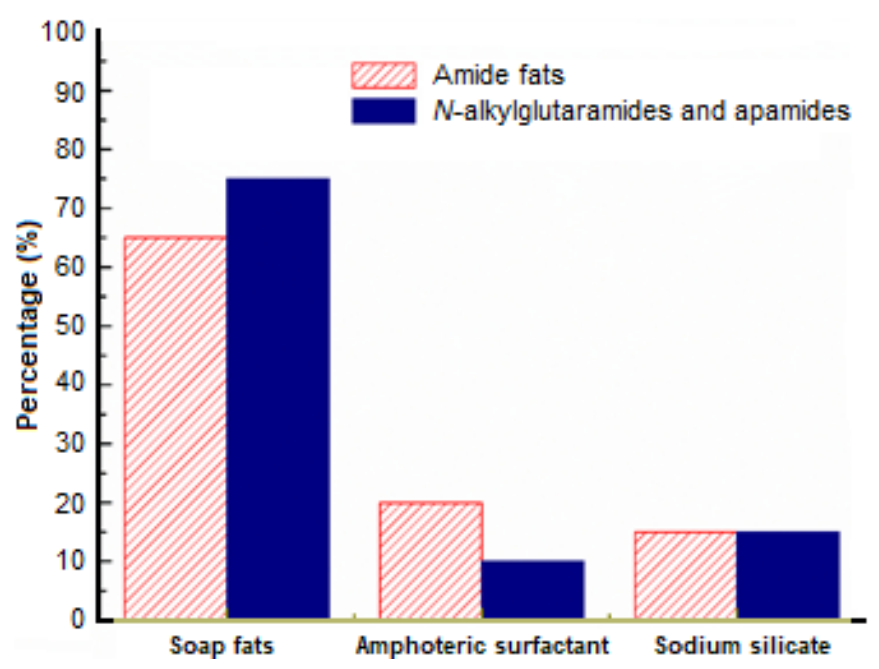

Fig 3. The results of a comparison of active surfaces between amide fats and $N$-alkylglutaramides and apamides [53]

Table 3. The comparison of sulfobetaine derivatives properties for detergents/surfactants

\begin{tabular}{|c|c|c|c|}
\hline Criteria & $\begin{array}{l}\text { Derivatives of sulfobetaine from } N \text { - } \\
\text { alkylglutaramides and adipamides }\end{array}$ & $\begin{array}{l}\text { Derivatives of sulfobetaine from } \\
\text { fatty amide }\end{array}$ & Ref. \\
\hline Dispersion ability & $\begin{array}{l}\text { Detergent formulations include lime } \\
\text { soap can stabilize calcium ions }\end{array}$ & $\begin{array}{l}\text { Detergent formulations include } \\
\text { ternary soap, glass silicate builder }\end{array}$ & {$[53-54]$} \\
\hline Detergency properties & $\begin{array}{l}\text { Succinamide analogs obtained } \\
\text { detergency properties }\end{array}$ & $\begin{array}{l}\text { Detergency properties were } \\
\text { obtained by ternary formulations, } \\
\text { which contain analogs sulfobetaine }\end{array}$ & {$[53-54]$} \\
\hline Solubility & Soluble in water & Soluble in water & {$[53-54]$} \\
\hline Purification & Requires high purification & Does not require purification & {$[53-54]$} \\
\hline Alkyl chain & $\begin{array}{l}\text { Alkyl side chains have } 12 \text { to } 14 \text { carbon } \\
\text { atoms }\end{array}$ & - & [54] \\
\hline Fat soap produced (\%) & 75 & 65 & {$[53-54]$} \\
\hline
\end{tabular}


damage and loss of function in biological media for a long-term application [34]. The weaknesses of methyl $\left(\mathrm{CH}_{3}\right)$ and OEG in terms of adhesion are active and diffused platelets, while in terms of resistance at a temperature of $23{ }^{\circ} \mathrm{C}$ high protein adsorption, especially for fibrinogen at $37{ }^{\circ} \mathrm{C}$, losing its repulsive protein properties [42].

PSB such as polyurethanes, silicone, cellulose, and polysulfone are applied to increase the blood compatibility of materials and anti-adhesive towards platelets, proteins, and microorganisms. Consequently, PSB derivatives are found in many medical applications. The anti-adhesive properties of the PSB-containing material result from the fact that the SB group fulfills all the requirements for anti-adhesive agents, high hydrophilicity, hydrogen bonding acceptors, and absence of donor hydrogen bonds, and electrical neutrality [55].

Zwitterionic material is auspicious as a nextgeneration biomaterial for various engineering and biomedical applications due to its excellent non-fouling properties in complex media. Furthermore, PSB and PCB have many attractive properties for practical applications, including ease of preparation, chemical stability, and low cost [34].

In the current study, three Self-Assembled Monolayers (SAM) were formed on the substrate (CH3), oligo (ethylene glycol)-termination (OEG), and initiator $\omega$-mercaptoundecyl bromoisobutyrate (Br) SAM [42].

The initial stage of blood platelet adhesion is the primary determiner in creating thrombosis and embolism. Based on the previous study, adhesion and platelet activation from blood flow are possibly correlated with the protein adsorption on the surface. As much as $75 \%$ of $\mathrm{CH} 3-\mathrm{SAM}$ is higher than OEG-SEM. However, there was a significant difference between OEG-SAM and polySBMA surface to hold the plasma protein adsorption. It includes the reduction of monoprotein adsorption as presented in Fig. 4, where the surface which was grafted on polySBMA rejected the plasma protein adsorption.

The stability of grafted zwitterionic sulfobetaine methacrylate (SBMA) antifouling surfaces is very distinctive regarding biological systems' biological elements and long-term structural stability. SBMA is grafted from a

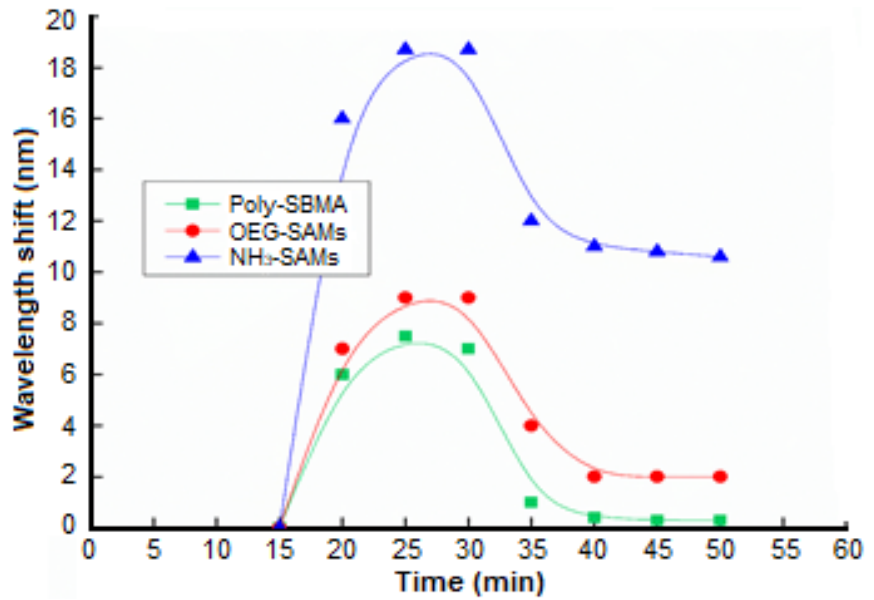

Fig 4. The level of protein adsorption from blood plasma [42]

gold-coated surface of bromide through radical polymerization, starting from the surface to form a wellpackaged polymer brush. Surface plasmon resonance sensors measured plasma proteins' adsorption on grafted PSBMA surfaces. It indicated that non-biofouling is very stable on both surfaces with grafted PSBMA could be carried out by the adsorption cycle test of three protein models in various types of salt, buffer composition, the $\mathrm{pH}$ level of the solution, and temperature. The adsorption of plasma protein and platelet adhesion from human blood plasma on PSBMA grafted surface efficiently minimizes plasma proteins' adsorption from low-platelet plasma solutions to higher levels of tetraterminated surface adsorption (ethylene glycol) [42].

The amount of plasma protein adsorbed was 38.25 $\mathrm{ng} / \mathrm{cm}^{2}$ on OEG-SAMs and $1.65 \mathrm{ng} / \mathrm{cm}^{2}$ on polySBMA surface. This fact indicates that polySBMA is a more effective alternative to prevent plasma protein adsorption from human blood at a temperature of $37^{\circ} \mathrm{C}$ (Table 4).

\section{Sulfobetaine Derivatives for Electronic Applications}

CPZ Interlayer can produce higher-efficient PTSBbased solar cells, while at the same time, using Ag electrode is more stable to replace $\mathrm{Ca} / \mathrm{Al}$ as the cathode. (Fig. 5) presents the CPZ performance which PSB combined. According to this figure, the current density of bare Ag is higher than PTSB and PTBTSB. The higher the current density, then the higher the voltage. Therefore, the derivatives of PSB can be applied in electronics. 
Table 4. The comparison of methyl, OEG, and PSBMA properties for biomedical applications

\begin{tabular}{|c|c|c|c|c|}
\hline Criteria & Methyl $\left(\mathrm{CH}_{3}\right)$ & $\begin{array}{l}\text { Oligo ethylene glycol } \\
\text { (OEG) }\end{array}$ & $\begin{array}{c}\text { Poly(sulfobetaine } \\
\text { methacrylate) (PSBMA) }\end{array}$ & Ref. \\
\hline Period & Short-term & Short-term & Long term & {$[42,56-57]$} \\
\hline Synthesis & Simple & Simple & Simple & {$[42,58]$} \\
\hline Raw material & Abundance & Abundance & Abundance & {$[42,58]$} \\
\hline Characteristic of surface & $\begin{array}{l}\text { Having a vulnerable } \\
\text { attraction towards } \\
\text { hydrophilic than the } \\
\text { hydrophobic surface }\end{array}$ & - & $\begin{array}{l}\text { A small amount of irreversibly } \\
\text { adsorbed fibrinogen and does } \\
\text { not depend on the protein } \\
\text { solution's ionic strength }\end{array}$ & {$[41,44]$} \\
\hline Adhesion & $\begin{array}{l}\text { Thrombocytes are still } \\
\text { spreading }\end{array}$ & $\begin{array}{l}\text { A few platelets are still } \\
\text { activated }\end{array}$ & There are no platelets attached & {$[34,42,55]$} \\
\hline Adsorption resistance & $\begin{array}{l}\text { At } 23{ }^{\circ} \mathrm{C} \text { has high protein } \\
\text { adsorption, especially for } \\
\text { fibrinogen }\end{array}$ & $\begin{array}{l}\text { At } 37^{\circ} \mathrm{C} \text { loses its protein } \\
\text { repulsive nature }\end{array}$ & $\begin{array}{l}\text { At } 37{ }^{\circ} \mathrm{C} \text { still maintains its } \\
\text { protein well }\end{array}$ & {$[34,42,55]$} \\
\hline $\begin{array}{l}\text { Adsorption rate at } 37^{\circ} \mathrm{C} \\
\left(\mathrm{ng} / \mathrm{cm}^{2}\right)\end{array}$ & 66.93 & 38.25 & 1.65 & {$[34,42,55]$} \\
\hline
\end{tabular}

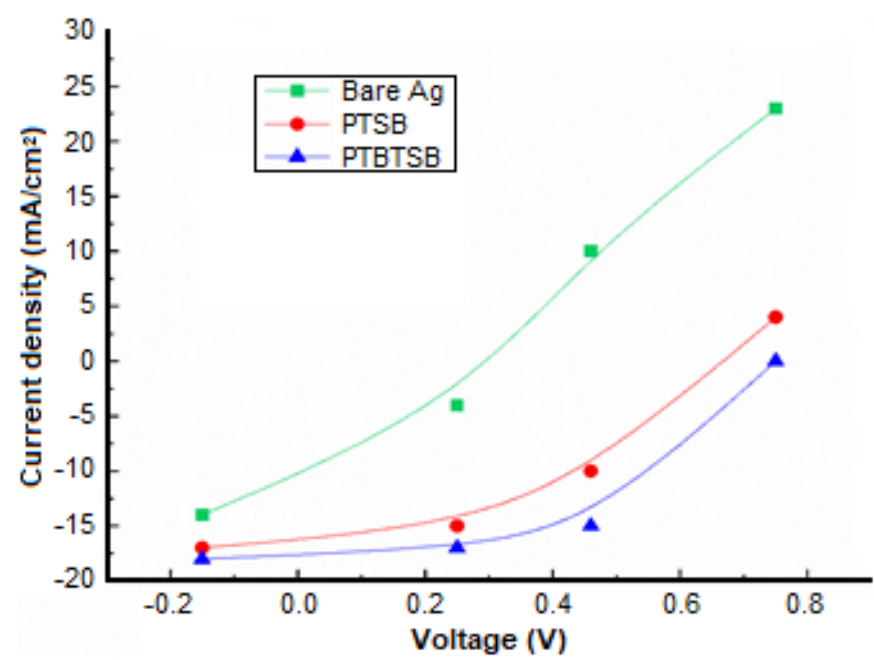

Fig 5. Interlayer performance containing CPZs [21]

Conjugated polymer zwitterions (CPZ) can be used as a new electronic material suitable for devices inside the electronics because it has easy synthesis, unique processing and solubility conditions, and the ability to interact with the metal substrate. CPZ is a neutral, hydrophilic, and polymer semiconductor. A zwitterion is soluble in a polar solvent and can be used as an optoelectronic device, such as metal electrodes and an active layer of an organic semiconductor. $\mathrm{CPZ}$ significantly determines the performance of organic electronics, such as the field-effect transistor (OFET), light-emitting diode (OLED), and photovoltaic (OPV). In the OPV, the interlayer function increases the different built-in electrics potential (Vbi) in all active layers and ensures the efficiency of the extracts bringing the photogeneration load. An active polar solvent is commonly electron-charged obtained to modify metal/organic electronic semiconductors' surface [21].

Apart from CPZ, CPE can also be applied as an interlayer material and also known to be soluble in a polar solvent, including water. Although $\mathrm{CPE}$ is more effective than CPZ, CPE also has weaknesses in its application in a very complex operation device. It is known that the derivative of sulfobetaine in the form of SB-CPZ is able to become good electronic because it coats the thin device or film on $\mathrm{Ag}$ (Silver) and $\mathrm{Au}$ (gold). SB-CPZ is applied in the electronic field as a biosensor and applied on active (Table 5).

\section{Sulfobetaine Derivatives for Surface Modification}

Sulfobetaine methacrylamide and carboxybetaine polymers are commonly used as nanocarriers, and the surface of these polymers can also be modified using UV irradiation. These polymers are synthesized via photoimmobilized on hydrophobic polymer substrates such as (polyester, polyethylene, and polystyrene) with direct covalent bonds to create a network by electrospinning from trifluoroethanol to form a nanofiber mat [65]. 
Table 5. The comparison of CPE, CPZ, and SB-CPZ properties for electrical applications

\begin{tabular}{|c|c|c|c|c|}
\hline Criteria & $\mathrm{CPE}$ & $\mathrm{CPZ}$ & SB-CPZ & Ref \\
\hline Properties & Effective and complete & $\begin{array}{l}\text { Neutral, hydrophilic, and } \\
\text { polymer semiconductor }\end{array}$ & $\begin{array}{l}\text { Polymer } \\
\text { electrolyte }\end{array}$ & {$[21,59-60]$} \\
\hline Solubility & Polar solvent & Polar solvent & $\begin{array}{l}\text { Soluble in salty water but } \\
\text { insoluble in almost all } \\
\text { organic solvent }\end{array}$ & {$[21,61]$} \\
\hline Interlayer & $\begin{array}{l}\text { As an interlayer material } \\
\text { in organic electronic }\end{array}$ & $\begin{array}{l}\text { As an interlayer material } \\
\text { in optoelectronic devices }\end{array}$ & $\begin{array}{l}\text { As an interlayer material in } \\
\text { optoelectronic devices }\end{array}$ & {$[21,62]$} \\
\hline Film form & Formed into thin films & $\begin{array}{l}\text { Used as thin-film layering } \\
\text { on metal }\end{array}$ & $\begin{array}{l}\text { Used as thin-film layering on } \\
\mathrm{Ag} \text { (silver) and } \mathrm{Au} \text { (gold) }\end{array}$ & {$[23,63]$} \\
\hline Application & OPVs, OLEDs & OLEDs, OPVs, OFET & Biosensor, active surfactant & {$[21,64]$} \\
\hline
\end{tabular}

Stimulus-responsive is a significant material in biotechnology, nanotechnology, and medicines because its properties can change and be controlled when responding to external stimulants. In the modification field, sulfobetaine has several benefits, such as delivery and separation, diagnostics, catalysis, and tissue engineering. On thermoresponsive material, there is a correlation between Low Critical Solution Temperature (LCST) and a polymer such as poly( $N$-isopropyl acrylamide) (PNIPAm). PNIPAm is a coil-to-globule transition, and due to the dehydration factor driven by entropy, it causes phase separation during heating. A binary mixture between water and alcohol (primarily ethanol) is beneficial for correct phase separation, reversed, and transition can be modulated. The second solvent's involvement can cause other solvents to be inhomogeneous, including the increase of polymer solubilities such as poly(methyl methacrylate) (PMMA) or polyoxazoline. PMMA is insoluble in pure water but soluble in ethanol-water mixtures with ethanol content range $(\mathrm{xEtOH})=0.50-1$.

On the other hand, a zwitterionic polymer of phosphorylcholine methacrylate is soluble in water and ethanol and has shown a suitability effect in ethanol content range $(\mathrm{xEtOH})=0.35-0.80$. PSB shows a strong intramolecular bonding interaction and chain interactions between the monomeric sulfate and ammonium groups, which are oppositely charged, causing reversible selfassociation. PSB also has high ionic properties, making it highly biocompatible with blood [66].

Fig. 6 indicates that the absorbance of Lactid Acid SulfoBetaine is higher than poly(LA-SB). Meanwhile, at the wavelength of $300 \mathrm{~nm}$, poly(LA-SB is lower than LA$\mathrm{SB}$. Therefore, it can be concluded that the derivatives of sulfobetaine can be used for surface modification.

PSB is a polymer that indicates zwitterionic UCST properties with a very strong hydrogen bond between molecules and can be applied in biomedical and biotechnology. PSB has a very ionic property, so than it has very high biocompatibility (Table 6). On the research conducted by Kollar et al., sulfobetaine-based polydisulfide with upper critical solution temperature (UCST) in the alcohol-water mix produced a result that the decrease of polarity and increase of ethanol percentage cause the increase of polymer cloud-point in the solution [66]. Polysulfide can also be applied as biomedical and biotechnology (Table 6).

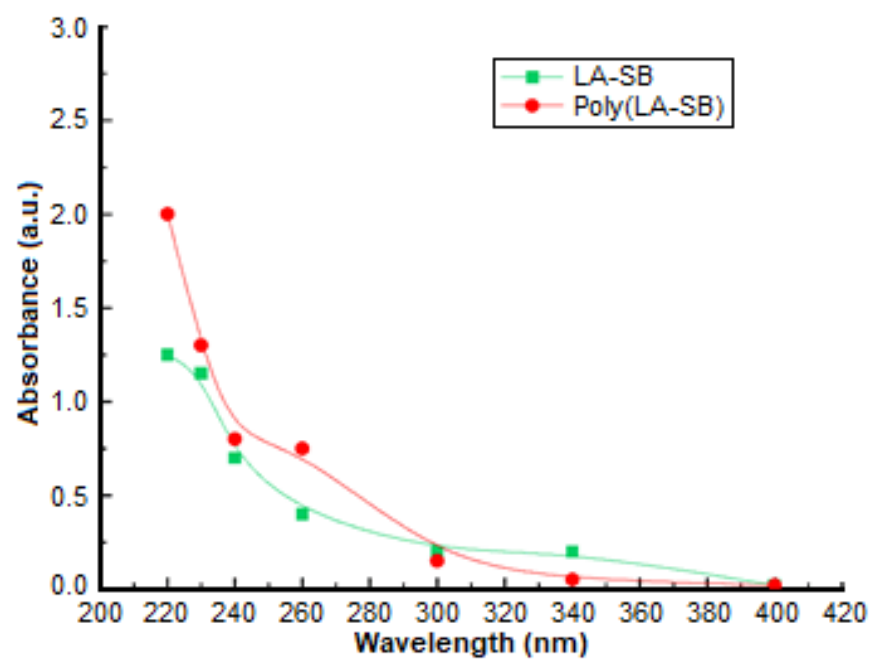

Fig 6. The absorbance of Lactic Acid-SulfoBetaine (LASB) and poly(Lactid Acid-SulfoBetaine) (poly(LA-SB) [66] 
Table 6. The comparison of polydisulfide and PSB properties for modification surface

\begin{tabular}{lllc}
\hline Criteria & \multicolumn{1}{c}{ Polydisulfide } & \multicolumn{1}{c}{ PSB } & Ref \\
\hline Solvent & Ethanol and water & Water or alcohol & {$[67-68]$} \\
Bond & Weak & Very strong & {$[66,69]$} \\
Properties & - & Very much ionic, so that it has & {$[70]$} \\
Cloud point & Lower than PSB & higher biocompatible & \\
Application & Biomedical and biotechnology & Higher than polydisulfide & {$[71-72]$} \\
\hline
\end{tabular}

\section{Sulfobetaine Derivatives for Smart Hydrogel}

Hydrogel helps the development of science in various fields of biomedicine and biotechnology. Polymeric hydrogel applications can be used as implants, medical and diagnostic equipment, release drugs, tissue engineering, enzyme and cell engineering, and others [66]. New smart hydrogel systems based on polyzwitterionic bearing sulfobetaine and carboxybetaine [75] or incorporated catecholic [76] with a new set of properties have been obtained and examined. On the base of energy conversion based on polyzwitterionic hydrogels, swelling and shrinking ability transform the antipolyelectrolyte effect into a mechanical force based on the salinity gradient. This phenomenon makes polyzwitterionic hydrogels suitable for use in an innovative polymeric engine [77].

Hydrogel polymers are different from polymer dressings and conventional elastomers. They are wet moist materials and responsive to stimulation and shockabsorbing due to their many particular deswelling properties. These properties enable them to be widely applied as cell scaffolds [78-82], drug delivery carriers [83-85], wound healing [86], antifouling coating [87-89], and artificial tissue replacement [90-91]. This material particularly has high water content and threedimensional porous tissue structure, providing an excellent biomimetic and biocompatible environment where cells and tissues can grow, thus regenerating tissues and organs [90-92]. Furthermore, to apply this material for wound healing, some unnecessary bio-adhesion must be avoided so that the host material function can be protected and preserved [93].

Dermal wound healing is a complicated mechanism that needs a balance interaction of cells, growth factors, and extracellular matrix proteins. This mechanism includes blood clotting, inflammation, new tissue development, and tissue rebuilding. Therefore, distinct biocompatible materials are needed to encapsulate antibacterial drugs [11] and specific growth factors [1213]. Thus it can handle these challenges. In these processes, the material matrix plays an essential and multifunctional role in anti-inflammatory regulation, bacterial finfection prevention, as well as providing a growth medium for cells in the wound healing process. As a result, developing non-fouling materials for wound healing is an important method for preventing capsule formation.

Fig. 7 shows that the wound healing closure of SBMA is higher than SBMA-PEG and PEG. The higher the wound healing closure, then the more times needed. It can be summed up that SBMA can be used as a smart hydrogel for wound healing applications.

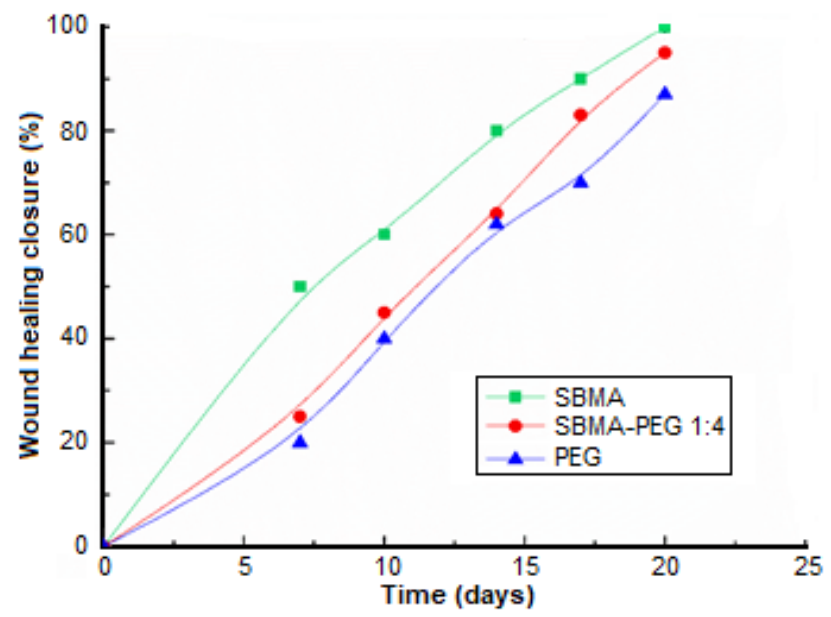

Fig 7. Wound closure of mice treated with SBMA and PEG [94] 
Table 7. The comparison of PEG and PSBMA properties in the form of a hydrogel

\begin{tabular}{|c|c|c|c|}
\hline Criteria & PEG & PSBMA & Ref \\
\hline Properties & Antifouling, easily oxidized & Antifouling & [4] \\
\hline Application & Wound healing & Wound healing & [94] \\
\hline Skin regeneration & $\begin{array}{l}\text { Less maximum in long-term } \\
\text { wound healing }\end{array}$ & Able to increase skin regeneration on wound & [95] \\
\hline Hydrogel bond & Easily break & Very strong & [96-97] \\
\hline Protein & $\begin{array}{l}\text { Decrease the bioactivity and } \\
\text { biostability of protein }\end{array}$ & $\begin{array}{l}\text { Maintain the bioactivity and biostability of the } \\
\text { original protein without artificial protein folding }\end{array}$ & {$[4,98]$} \\
\hline
\end{tabular}

Hydrogel polymer has much uniqueness, including easily expands, responsive towards stimulation, and readily adsorb, so that it is numerously used as a scaffold on cells, cells, wound healing, antifouling coating, and changing the artificial tissue (Table 7). PSBMA is a hydrophilic or zwitterionic antifouling hydrogel. Dehydration on the hydrogel surface is considered a hydrogel antifouling property factor since the tightly tied water bond forms a physical and energetic water layer to prevent unwanted foulant adsorption. However, the dehydration layer on different hydrogel surfaces can be achieved differently [94].

\section{- CONCLUSION}

PSB derivatives have been utilized in various fields and sectors. PSB as an adsorbing agent (antimicrobial) is known to have been widely used starting in 2005 by several researchers. Compared to Peptidomimetic polymers, poly(sulfobetaine-3,4-ethylenedioxythiophene) and poly(sulfobetaine-3,4-ethylenedioxythiophene) are better materials for adsorption due to their low plasma and serum adsorption resistance parameter. Also, the plasma surface adsorption parameter for sulfobetaine derivatives is $100 \%$, compared to peptidomimetic polymers (75\%) make these derivatives are suitable for bioelectronics and adsorption protein for medical purposes.

PSB as antifouling has several advantages over PEG, such as their solubility properties in water without using surfactant or organic solvents, while PEG needs biosurfactants to be soluble in water. Besides, PSB also has protein adsorption by $28 \%$ and reduces bacterial adhesion by $96.7 \%$. So based on the previous finding, it is known that the adhesion power of PSB tends to be higher than the adsorption power. Therefore, PSB is widely used on membrane separation and marine coating.
SB derivatives in the form of surfactants and detergents have been available since 1982. Based on the existing detergent formulation data, detergents made from sulfobetaine derivatives in $\mathrm{N}$-alkylglutaramides and apamides can produce fat soap with a higher percentage than that of ammonium sulfobetaine derivatives. In recent years, compared to materials Methyl $\left(\mathrm{CH}_{3}\right)$ and Oligo ethylene glycol (OEG), the development of PSB for biomedical purposes is widely developed due to their long-term stability, relatively simple synthesis process, no platelet adhesion attached, and the ability to maintaining the protein well at a temperature of $37^{\circ} \mathrm{C}$.

Conjugated polymer zwitterions (CPZ) can be used as a new electronic material suitable for the device inside the electronics. The comparison of CPE, CPZ, and SB-CPZ properties for electrical applications results that SB-CPZ can become good electronic because it coats the thin device or film on Ag (Silver) and Au (gold). CPZ$\mathrm{SB}$ is applied in the electronic field as a biosensor and interlayer material. PSB modification has several benefits: delivery and separation, diagnostics, catalysis, and tissue engineering. Compared to polysulfide, PSB shows a strong intramolecular bonding interaction and chain interactions between the monomeric sulfate and ammonium groups, which are oppositely charged, causing reversible self-association. PSB also has high ionic properties, making it highly biocompatible with blood.

PSBMA is a hydrophilic or zwitterionic antifouling hydrogel that has much uniqueness, including easily expands, being responsive towards stimulation, and readily adsorb, so that it is numerously used as a scaffold on cells, wound healing, antifouling coating, and changing the artificial tissue. Compared to PEG, PSBMA 
has a very strong hydrogel bond that could maintain the original protein's bioactivity and biostability without artificial protein folding.

\section{- ACKNOWLEDGMENTS}

The current review was supported by a Research Grant of Penelitian Dasar Unggulan Perguruan Tinggi 2020 from the Ministry of Research and Technology/National Research and Innovation Agency (Kemenristek/BRIN) (1198/PKS/ITS/2020).

\section{- REFERENCES}

[1] He, M., Gao, K., Zhou, L., Jiao, Z., Wu, M., Cao, J., You, X., Cai, Z., Su, Y., and Jiang, Z., 2016, Zwitterionic materials for antifouling membrane surface construction, Acta Biomater., 40, 142-152.

[2] Shao, Q., and Jiang, S., 2014, Molecular understanding and design of zwitterionic, Adv. Mater., 27 (1), 15-26.

[3] Zou, H., Wang, Z., and Feng, M., 2015, Nanocarriers with tunable surface properties to unblock bottlenecks in systemic drug and gene delivery, $J$. Controlled Release, 214, 121-133.

[4] He, Y., Hower, J., Chen, S., Bernards, M.T., Chang, Y., and Jiang, S., 2008, Molecular simulation studies of protein interactions with zwitterionic phosphorylcholine self-assembled monolayers in the presence of water, Langmuir, 24 (18), 10358-10364.

[5] Schlenoff, J.B., 2014, Zwitteration: Coating surfaces with zwitterionic functionality to reduce nonspecific adsorption, Langmuir, 30 (32), 9625-9636.

[6] Suprapto, S., Gotoh, T., Humaidah, N., Febryanita, R., Firdaus, M.S., and Ningrum, E.O., 2020, The effect of synthesis condition of the ability of swelling, adsorption, and desorption of zwitterionic sulfobetaine-based gel, Int. J. Technol., 11 (2), 299-309.

[7] Ningrum, E.O., Sakohara, S., Gotoh, T., Suprapto, and Humaidah, N., 2020, Correlating properties between sulfobetaine hydrogels and polymers with different carbon spacer lengths, Polymer, 186, 122013.

[8] Ningrum, E.O., Purwanto, A., Rosita, G.C., and Bagus, A., 2020, The properties of thermosensitive zwitterionic sulfobetaine NIPAM-co-DMAAPS polymer and the hydrogels: The effects of monomer concentration on the transition temperature and its correlation with the adsorption behavior, Indones.J. Chem., 20 (2), 324-335.

[9] Ningrum, E.O., Bagus, A., Agustiani, E., and Ni'mah, H., 2020, Thermosensitive and chitosan of crab (Portunus pelagicus) shells gel based adsorbent for reversible adsorption-desorption of several toxic metal ions, IOP Conf. Ser.: Earth Environ. Sci., 460, 012017.

[10] Salamone, J.C., Volksen, W., Olson, A.P., and Israel, S.C., 1978, Aqueous solution properties of a poly(vinyl imidazolium sulphobetaine), Polymer, 19 (10), 1157-1162.

[11] Takahashi, A., Hamai, K., Okada, Y., and Sakohara, S., 2011, Thermosensitive properties of semi-IPN gel composed of amphiphilic gel and zwitterionic thermosensitive polymer in buffer solutions containing high concentration salt, Polymer, 52 (17), 3791-3799.

[12] Kudaibergenov, S., Jaeger, W., and Laschewsky, A., 2006, Polymeric betaines: Synthesis, characterization, and application, Adv. Polym. Sci., 201, 157-224.

[13] Ningrum, E.O., Sakohara, S., Gotoh, T., Suprapto, and Humaidah, N., 2019, The effect of cation and anion species on the transition and adsorption behaviors of thermosensitive sulfobetaine gelbased adsorbent, Int. J. Technol., 10 (3), 443-452.

[14] Zheng, L., Sundaram, H.S., Wei, Z., Li, C., and Yuan, Z., 2017, Applications of zwitterionic polymers, React. Funct. Polym., 118, 51-61.

[15] Lowe, A.B., and McCormick, C.L., 2002, Synthesis and solution properties of zwitterionic polymers, Chem. Rev., 102 (11), 4177-4190.

[16] Yakimova, L.S., Padnya, P.L., Kunafina, A.F., Nugmanova, A.R., and Stoikov, I.I., 2019, Sulfobetaine derivatives of thiacalix[4]arene: Synthesis and supramolecular self-assembly of submicron aggregates with $\mathrm{Ag}^{\mathrm{I}}$ cations, Mendeleev Commun., 29 (1), 86-88.

[17] Yakimova, L., Padnya, P., Tereshina, D., Kunafina, A., Nugmanova, A., Osin, Y., Evtugyn, V., and Stoikov, I., 2019, Interpolyelectrolyte mixed nanoparticles from anionic and cationic 
thiacalix[4]arenes for selective recognition of model biopolymers, J. Mol. Liq., 279, 9-17.

[18] Shurpik, D.N., Sevastyanov, D.A., Zelenikhin, P.V, Padnya, P.L., Evtugyn, V.G., Osin, Y.N., and Stoikov, I.I., 2020, Nanoparticles based on the zwitterionic pillar[5]arene and $\mathrm{Ag}^{+}$: Synthesis, self-assembly and cytotoxicity in the human lung cancer cell line A549, Beilstein J. Nanotechnol., 11, 421-431.

[19] Yan, M., Ge, J., Dong, W., Liu, Z., and Ouyang, P., 2006, Preparation and characterization of a temperature-sensitive sulfobetaine polymer-trypsin conjugate, Biochem. Eng. J., 30 (1), 48-54.

[20] Kasák, P., Mosnáček, J., Danko, M., Krupa, I., Hloušková, G., Chorvát, D., Koukaki, M., Karamanou, S., Economou, A., and Lacík, I., 2016, A polysulfobetaine hydrogel for immobilization of glucose-binding protein, RSC Adv., 6, 83890-83900.

[21] Liu, Y., Duzhko, V.V, Page, Z.A., Emrick, T., and Russell, T.P., 2016, Conjugated polymer zwitterions: Efficient interlayer materials in organic electronics, Acc. Chem. Res., 49 (11), 2478-2488.

[22] Lee, H., Puodziukynaite, E., Zhang, Y., Stephenson, J.C., Richter, L.J., Fischer, D.A., DeLongchamp, D.M., Emrick, T., and Briseno, A.L., 2015, Poly(sulfobetaine methacrylate)s as electrode modifiers for inverted organic electronics, J. Am. Chem. Soc., 137 (1), 540-549.

[23] Fang, J., Wallikewitz, B.H., Gao, F., Tu, G., Müller, C., Pace, G., Friend, R.H., and Huck, W.T.S., 2011, Conjugated zwitterionic polyelectrolyte as the charge injection layer for high-performance polymer lightemitting diodes, J. Am. Chem. Soc., 133 (4), 683-685.

[24] Arotçaréna, M., Heise, B., Ishaya, S., and Laschewsky, A., 2002, Switching the inside and the outside of aggregates of water-soluble block copolymers with double thermoresponsivity, J. Am. Chem. Soc., 124, 3787-3793.

[25] Ladd, J., Zhang, Z., Chen, S., Hower, J.C., and Jiang, S., 2008, Zwitterionic polymers exhibiting high resistance to nonspecific protein adsorption from human serum and plasma, Biomacromolecules, 9 (5), 1357-1361.
[26] Li, A., Luehmann, H.P., Sun, G., Samarajeewa, S., Zou, J., Zhang, S., Zhang, F., Welch, M.J., Liu, Y., and Wooley, K.L., 2012, Synthesis and in vivo pharmacokinetic evaluation of degradable shell cross-linked polymer nanoparticles with poly(carboxybetaine) versus poly(ethylene glycol) surface-grafted coatings, ACS Nano, 6 (10), 89708982.

[27] Statz, A.R., Meagher, R.J., Barron, A.E., and Messersmith, P.B., 2005, New peptidomimetic polymers for antifouling surfaces, J. Am. Chem. Soc., 127 (22), 7972-7973.

[28] Li, G., Cheng, G., Xue, H., Chen, S., Zhang, F., and Jiang, S., 2008, Ultra low fouling zwitterionic polymers with a biomimetic adhesive group, Biomaterials, 29 (35), 4592-4597.

[29] Chen, S., Zheng, J., Li, L., and Jiang, S., 2005, Strong resistance of phosphorylcholine self-assembled monolayers to protein adsorption: Insights into nonfouling properties of zwitterionic materials, $J$. Am. Chem. Soc., 127 (41), 14473-14478.

[30] Chang, Y., Chen, S., Zhang, Z., and Jiang, S., 2006, Highly protein-resistant coatings from welldefined diblock copolymers containing sulfobetaines, Langmuir, 22 (5), 2222-2226.

[31] Zhang, Z., Chen, S., Chang, Y., and Jiang, S., 2006, Surface grafted sulfobetaine polymers via atom transfer radical polymerization as superlow fouling coatings, J. Phys. Chem. B, 110 (22), 10799-10804.

[32] Zhang, Z., Chao, T., Chen, S., and Jiang, S., 2006, Superlow fouling sulfobetaine and carboxybetaine polymers on glass slides, Langmuir, 22 (24), 1007210077.

[33] Zhang, Z., Chen, S., and Jiang, S., 2006, Dualfunctional biomimetic materials: Nonfouling poly(carboxybetaine) with active functional groups for protein immobilization, Biomacromolecules, 7 (12), 3311-3315.

[34] Jiang, S., and Cao, Z., 2010, Ultralow-fouling, functionalizable, and hydrolyzable zwitterionic materials and their derivatives for biological applications, Adv. Mater., 22 (9), 920-932. 
[35] Cao, B., Lee, C.J., Zeng, Z., Cheng, F., Xu, F., Cong, H., and Cheng, G., 2016, Electroactive poly(sulfo betaine-3,4-ethylenedioxythiophene) (PSBEDOT) with controllable antifouling and antimicrobial properties, Chem. Sci., 7 (3), 1976-1981.

[36] Simon, R.J., Kania, R.S., Zuckermann, R.N., Huebner, V.D., Jewell, D.A., Banville, S., Ng, S., Wang, L., Rosenberg, S., Marlowe, C.K., 1992, Peptoids: A modular approach to drug discovery, Proc. Natl. Acad. Sci. U.S.A., 89 (20), 9367-9371.

[37] Ouyang, J., Chu, C.W., Chen, F., Xu, Q., and Yang, Y., 2005, High-conductivity poly(3,4-ethylenedioxy thiophene): Poly(styrene sulfonate) film and its application in polymer optoelectronic devices, $A d v$. Funct. Mater., 15 (2), 203-208.

[38] Sotzing, G.A., Reynolds, J.R., and Steel, P.J., 1991, Poly(3,4-ethylenedioxythiophene) (PEDOT) prepared via electrochemical polymerization of EDOT, 2,2'Bis(3,4-ethylenedioxythiophene) (BiEDOT), and their TMS derivatives, Adv. Mater., 9 (10), 795-798.

[39] Gaupp, C.L., Zong, K., Schottland, P., Thompson, B.C., Thomas, C.A., and Reynolds, J.R., 2000, Poly(3,4-ethylenedioxypyrrole): Organic electro chemistry of a highly stable electrochromic polymer, Macromolecules, 33 (4), 1132-1133.

[40] Erb, B.T., Zhokhavets, U., Gobsch, G., Raleva, S., Stühn, B., Schilinsky, P., Waldauf, C., and Brabec, C.J., 2005, Correlation between structural and optical properties of composite polymer/fullerene films for organic solar cells, Adv. Funct. Mater., 15 (7), 11931196.

[41] Patch, J.A., and Barron, A.E., 2002, Mimicry of bioactive peptides via non-natural, sequence-specific peptidomimetic oligomers, Curr. Opin. Chem. Biol., 6 (6), 872-877.

[42] Chang, Y., Liao, S.C., Higuchi, A., Ruaan, R.C., Chu, C.W., and Chen, W.Y., 2008, A highly stable nonbiofouling surface with well-packed grafted zwitterionic polysulfobetaine for plasma protein repulsion, Langmuir, 24 (10), 5453-5458.

[43] Sun, Q., Su, Y., Ma, X., Wang, Y., and Jiang, Z., 2006, Improved antifouling property of zwitterionic ultrafiltration membrane composed of acrylonitrile and sulfobetaine copolymer, J. Membr. Sci., 285 (1), 299-305.

[44] Wei, J., Ravn, D.B., Gram, L., and Kingshott, P., 2003, Stainless steel modified with poly(ethylene glycol) can prevent protein adsorption but not bacterial adhesion, Colloids Surf., B, 32 (4), 275-291.

[45] Guo, W., Ngo, H., and Li, J., 2012, A mini-review on membrane fouling, Bioresour. Technol., 122, 2734.

[46] Hadidi, M., and Zydney, A.L., 2014, Fouling behavior of zwitterionic membranes: Impact of electrostatic and hydrophobic interactions, $J$. Membr. Sci., 452, 97-103.

[47] Ginic-Markovic, M., Barclay, $\quad$ T.G., Constantopoulos, K.T., Markovic, E., Clarke, S.R., and Matisons, J.G., 2015, Biofouling resistance of polysulfobetaine coated reverse osmosis membranes, Desalination, 369, 37-45.

[48] Ostuni, E., Chapman, R.G., Holmlin, R.E., Takayama, S., and Whitesides, G.M., 2001, A survey of structure-property relationships of surfaces that resist the adsorption of protein, Langmuir, 17 (18), 5605-5620.

[49] Sin, M.C., Chen, S.H., and Chang, Y., 2014, Hemocompatibility of zwitterionic interfaces and membranes, Polym. J., 46 (8), 436-443.

[50] Matyjaszewski, K., Dong, H., Jakubowski, W., Pietrasik, J., and Kusumo, A., 2007, Grafting from surfaces for "Everyone": ARGET ATRP in the presence of air, Langmuir, 23 (8), 4528-4531.

[51] Gillich, T., Benetti, E.M., Rakhmatullina, E., Konradi, R., Li, W., Zhang, A., Schlüter, A.D., and Textor, M., 2011, Self-assembly of focal point oligocatechol ethylene glycol dendrons on titanium oxide surfaces: Adsorption kinetics, surface characterization, and nonfouling properties, J. Am. Chem. Soc., 133, 10940-10950.

[52] Hjelmeland, L.M., Nebert, D.W., and Osborne, J.C., 1983, Sulfobetaine derivatives of bile acids: Nondenaturing surfactants for membrane biochemistry, Anal. Biochem., 130 (1), 72-82.

[53] Parris, N., Pierce, C., and Linfield, W.M., 1977, Soap based detergent formulation: XXIV. Sulfobetaine 
derivatives of fatty amides, J. Am. Oil Chem. Soc., 54 (7), 294-296.

[54] Micich, T.J., and Linfield, W.M., 1977, Soap-based detergent formulations: XXII. Sulfobetaine derivatives of $\mathrm{N}$-alkylglutaramides and adipamides, J. Am. Oil Chem. Soc., 54 (6), 264-266.

[55] Gaweł, K., Szczubiałka, K., Zapotoczny, S., and Nowakowska, M., 2010, Zwitterionically modified hydroxypropylcellulose for biomedical applications, Eur. Polym. J., 46 (7), 1475-1479.

[56] Dupont-Gillain, C.C., Fauroux, C.M.J., Gardner, D.C.J., and Leggett, G.J., 2003, Use of AFM to probe the adsorption strength and time-dependent changes of albumin on self-assembled monolayers, J. Biomed. Mater. Res., Part A, 67A (2), 548-558.

[57] Teramura, Y., and Iwata, H., 2010, Cell surface modification with polymers for biomedical studies, Soft Matter, 6 (6), 1081-1091.

[58] Chen, S., Li, L., Zhao, C., and Zheng, J., 2010, Surface hydration: Principles and applications toward lowfouling/nonfouling biomaterials, Polymer, 51 (23), 5283-5293.

[59] Li, H., Xu, Y., Hoven, C.V., Li, C., Seo, J.H., and Bazan, G.C., 2009, Molecular design, device function and surface potential of zwitterionic electron injection layers, J. Am. Chem. Soc., 131 (25), 8903-8912.

[60] Tordera, D., Kuik, M., Rengert, Z.D., Bandiello, E., Bolink, H.J., Bazan, G.C., and Nguyen, T.Q., 2014, Operational mechanism of conjugated polyelectrolytes operational mechanism of conjugated polyelectrolytes, J. Am. Chem. Soc., 136 (24), 8500-8503.

[61] Chueh, C.C., Li, C.Z., and Jen, A.K.Y., 2015, Recent progress and perspective in solution-processed Interfacial materials for efficient and stable polymer and organometal perovskite solar cells, Energy Environ. Sci., 8 (4), 1160-1189.

[62] Huang, F., Wu, H., and Cao, Y., 2010, Water/alcohol soluble conjugated polymers as highly efficient electron transporting/injection layer in optoelectronic devices, Chem. Soc. Rev., 39 (7), 25002521.

[63] Duan, C., Zhang, K., Zhong, C., Huang, F., and Cao, Y., 2013, Recent advances in water/alcohol-soluble p-conjugated materials: New materials and growing applications in solar cells, Chem. Soc. Rev., 42 (23), 9071-9104.

[64] He, Z., Wu, H., and Cao, Y., 2014, Recent advances in polymer solar cells: Realization of high device performance by incorporating water/alcoholsoluble conjugated polymers as electrode buffer layer, Adv. Mater., 26 (7), 1006-1024.

[65] Sobolčiak, P., Popelka, A., Mičušík, M., Sláviková, M., Krupa, I., Mosnáček, J., Tkáč, J., Lacík, I., and Kasák, P., 2017, Photoimmobilization of zwitterionic polymers on surfaces to reduce cell adhesion, J. Colloid Interface Sci., 500, 294-303.

[66] Kollar, J., Popelka, A., Tkáć, J., Žabka, M., Mosnáček, J., and Kasák, P., 2021, Sulfobetainebased polydisulfides with tunable upper critical solution temperature (UCST) in water alcohols mixture, depolymerization kinetics and surface wettability, J. Colloid Interface Sci., 588, 196-208.

[67] Hoogenboom, R., Becer, C.R., Guerrero-Sanchez, C., Hoeppener, S., and Schubert, U.S., 2010, Solubility and thermoresponsiveness of PMMA in alcohol-water solvent mixtures, Aust. J. Chem., 63 (8), 1173-1178.

[68] Matsuda, Y., Kobayashi, M., Annaka, M., Ishihara, K., and Takahara, A., 2008, UCST-type cononsolvency behavior of $\operatorname{poly}(2-$ methacryloxyethyl phosphorylcholine) in the mixture of water and ethanol, Polym. J., 40 (5), 479483.

[69] Seuring, J., and Agarwal, S., 2012, Polymers with upper critical solution temperature in aqueous solution, Macromol. Rapid Commun., 33 (22), 1898-1920.

[70] Seuring, J., and Agarwal, S., 2013, Polymers with upper critical solution temperature in aqueous solution: Unexpected properties from known building blocks, ACS Macro Lett., 2 (7), 597-600.

[71] Blackman, L.D., Gunatillake, P.A., Cass, P., and Locock, K.E.S., 2019, An introduction to zwitterionic polymer behavior and applications in solution and at surfaces, Chem. Soc. Rev., 48 (3), 757-770. 
[72] Wood, P.A., Zhu, Y., Pei, Y., and Roth, P.J., 2014, Hydrophobically modified sulfobetaine copolymers with tunable aqueous UCST through postpoly merization modification of poly(pentafluorophenyl acrylate), Macromolecules, 47 (2), 750-762.

[73] Li, D., Wei, Q., Wu, C., Zhang, X., Xue, Q., Zheng, T., and Cao, M., 2020, Superhydrophilicity and strong salt-affinity: Zwitterionic polymer grafted surfaces with significant potentials particularly in biological systems, Adv. Colloid Interface Sci., 278, 102141.

[74] Zhou, L., Zhu, Y., Wang, X., Shen, C., Wei, X., Xu, T., and He, Z., 2020, Novel zwitterionic vectors: Multifunctional delivery systems for therapeutic genes and drugs, Comput. Struct. Biotechnol. J., 18, 1980-1999

[75] Danko, M., Kroneková, Z., Mrlik, M., Osicka, J., bin Yousaf, A., Mihálová, A., Tkac, J., and Kasak, P., 2019, Sulfobetaines meet carboxybetaines: Modulation of thermo- and ion-responsivity, water structure, mechanical properties and cell adhesion, Langmuir, 35 (5), 1391-1403.

[76] Mrlík, M., Špírek, M., Al-Khori, J., Ahmad, A.A., Mosnaček, J., AlMaadeed, M.A.A., and Kasák, P., 2020, Mussel-mimicking sulfobetaine-based copolymer with metal tunable gelation, self-healing and antibacterial capability, Arabian J. Chem., 13 (1), 193-204.

[77] Zavahir, S., Krupa, I., AlMaadeed, S.A., Tkac, J., and Kasak, P., 2019, Polyzwitterionic hydrogels in engines based on the antipolyelectrolyte effect and driven by the salinity gradient, Environ. Sci. Technol., 53 (15), 9260-9268.

[78] Söntjens, S.H.M., Nettles, D.L., Carnahan, M.A., Setton, L.A., and Grinstaff, M.W., 2006, Biodendrimer-based hydrogel scaffolds for cartilage tissue repair, Biomacromolecules, 7 (1), 310-316.

[79] Balakrishnan, B., and Banerjee, R., 2011, Biopolymer-based hydrogels for cartilage tissue engineering, Chem. Rev., 111 (8), 4453-4474.

[80] Lee, K.Y., and Mooney, D.J., 2001, Hydrogels for tissue engineering, Chem. Rev., 101, 1869-1880.

[81] Wang, F., Li, Z., Khan, M., Tamama, K., Kuppusamy, P., Wagner, W.R., Sen, C.K., and Guan, J., 2010,
Injectable, rapid gelling and highly flexible hydrogel composites as growth factor and cell carriers, Acta Biomater., 6 (6), 1978-1991.

[82] Wu, J., Ding, Q., Dutta, A., Wang, Y., Huang, Y., Weng, H., Tang, L., and Hong, Y., 2015, An injectable extracellular matrix derived hydrogel for meniscus repair and regeneration, Acta Biomater., $16,49-59$.

[83] Jaiswal, M., Dinda, A.K., Gupta, A., and Koul, V., 2010, Polycaprolactone diacrylate crosslinked biodegradable semi-interpenetrating networks of polyacrylamide and gelatin for controlled drug delivery, Biomed. Mater., 5 (6), 065014.

[84] Zhao, C., Patel, K., Aichinger, L.M., Liu, Z., Hu, R., Chen, H., Li, X., Li, L., Zhang, G., Chang, Y., and Zheng, J., 2013, Antifouling and biodegradable poly( $N$-hydroxyethyl acrylamide) (polyHEAA)based nanogels, RSC Adv., 3 (43), 19991-20000.

[85] Gu, X., Ning, Y., Yang, Y., and Wang, C., 2014, One-step synthesis of porous graphene-based hydrogels containing oil droplets for drug delivery, RSC Adv., 4 (7), 3211-3218.

[86] Masters, K.S.B., Leibovich, S.J., Belem, P., West, J.L., and Poole-Warren, L.A., 2002, Effects of nitric oxide releasing poly(vinyl alcohol) hydrogel dressings on dermal wound healing in diabetic mice, Wound Repair Regen., 10 (5), 286-294.

[87] Holland, T.A., Tessmar, J.K.V., Tabata, Y., and Mikos, A.G., 2004, Transforming growth factor- $\beta 1$ release from oligo(poly(ethylene glycol) fumarate) hydrogels in conditions that model the cartilage wound healing environment, J. Controlled Release, 94 (1), 101-114.

[88] Ekblad, T., Bergström, G., Ederth, T., Conlan, S.L., Mutton, R., Clare, A.S., Wang, S., Liu, Y., Zhao, Q., D'Souza, F., Donnelly G.T., Willemsen, P.R., Pettitt, M.E., Callow, M.E., Callow, J.A., and Liedberg, B., 2008, Poly(ethylene glycol)-Containing hydrogel surfaces for antifouling applications in marine and freshwater environments, Biomacromolecules, 9 (10), 2775-2783.

[89] Zhao, C., Li, X., Li, L., Cheng, G., Gong, X., and Zheng, J., 2013, Dual functionality of antimicrobial 
and antifouling of poly( $N$-hydroxyethylacrylamide)/ salicylate hydrogels, Langmuir, 29 (5), 1517-1524.

[90] Hoffman, A.S., 2012, Hydrogels for biomedical applications, Adv. Drug Delivery Rev., 64, 18-23.

[91] Chen, Q., Chen, H., Zhu, L., and Zheng, J., 2015, Fundamentals of double network hydrogels, J. Mater. Chem. B, 3 (18), 3654-3676.

[92] Elliott, N.T., and Yuan, F., 2011, A review of threedimensional in vitro tissue models for drug discovery and transport studies, J. Pharm. Sci., 100, 2-8.

[93] Steward, A.J., Liu, Y., and Wagner, D.R., 2011, Engineering cell attachments to scaffolds in cartilage tissue engineering, Biomater. Regener. Med., 63 (4), 74-82.

[94] Wu, J., Xiao, Z., Chen, A., He, H., He, C., Shuai, X., Li, X., Chen, S., Zhang, Y., Ren, B., Zheng, J., and Xiao, J., 2018, Sulfated zwitterionic poly(sulfobetaine methacrylate) hydrogels promote complete skin regeneration, Acta Biomater., 71, 293-305.

[95] Chang, Y., Shu, S., Shih, Y., Chu, C., Ruaan, R., and Chen, W., 2010, Hemocompatible mixed-charge copolymer brushes of pseudozwitterionic surfaces resistant to nonspecific plasma protein fouling, Langmuir, 26, 3522-3530.

[96] Jiang, S., and Cao, Z., 2010, Ultralow-fouling, functionalizable, and hydrolyzable zwitterionic materials and their derivatives for biological applications, Adv. Mater., 22 (9), 920-932.

[97] Chen, S., Li, L., Zhao, C., and Zheng, J., 2010, Surface hydration: Principles and applications toward low-fouling/nonfouling biomaterials, Polymer, 51 (23), 5283-5293.

[98] Keefe, A.J., and Jiang, S., 2012, Poly(zwitterionic)protein conjugates offer increased stability without sacrificing binding affinity or bioactivity, Nat. Chem., 4 (1), 59-63. 